\section{Effects of age, period, and birth cohort on homicide mortality in the city of São Paulo, Brazil, from 1996 to 2015}

\author{
Efeitos de idade, período e coorte de nascimentos \\ sobre mortalidade por homicídio na cidade de \\ São Paulo, Brasil, entre 1996 e 2015
}

Flávia Reis de Andrade 1

Fabrício dos Santos Menezes 2

Max Moura de Oliveira 3

Gleice Margarete de Souza Conceição 4

Maria Fernanda Tourinho Peres 5,6

Maria do Rosário Dias de Oliveira Latorre 4

\begin{abstract}
Although São Paulo is the most populous city in Brazil - one of the world's most violent countries - a significant reduction in its homicide mortality rate (HMR) has been detected. This study aims to estimate the effects of age, period, and birth cohort on the trend of homicide mortality according to sex in the city of São Paulo, from 1996 to 2015. An ecological study was undertaken with data on deaths by homicide for both sexes, in all age brackets, in the city of São Paulo. Poisson models were adjusted for each sex to estimate the age-periodcohort effects. In total, 61,833 deaths by homicide were recorded among males and 5,109 among females. Regardless of the period, the highest HMR occurred in the 20-24 age bracket. Higher HMRs were found in those born in the 1970s and 1980s. The complete model, with age-period-cohort effects, were the best fit to the data. The risk of death by homicide declined over the periods, with lower intensity in the final five years (2011-2015), for both males $(R R=0.48$; 95\%CI: $0.46 ; 0.49)$ and females $(R R=0.52 ; 95 \% C I: 0.47 ; 0.57)$. A reduction was found in the risk of homicide, regardless of the sex or age bracket, and also in recent cohorts. However, the intensity of such reductions has been decreasing over time, which suggests that the public policies adopted have limited potential to maintain these achievements.
\end{abstract}

Homicide; Age Effect; Period Effect; Cohort Effect

\author{
Correspondence \\ F. R. Andrade \\ Centro Metropolitano, Conjunto A, Lote 01, Ceilândia, DF \\ 72220-900, Brasil. \\ flaviaandrade@unb.br \\ 1 Faculdade de Ceilândia, Universidade de Brasília, Ceilândia, \\ Brasil. \\ 2 Departamento de Educação em Saúde, Universidade Federal de \\ Sergipe, Lagarto, Brasil. \\ 3 Instituto de Patologia Tropical e Saúde Pública, Universidade \\ Federal de Goiás, Goiânia, Brasil. \\ 4 Faculdade de Saúde Pública, Universidade de São Paulo, \\ São Paulo, Brasil. \\ 5 Faculdade de Medicina, Universidade de São Paulo, \\ São Paulo, Brasil. \\ ${ }^{6}$ Laboratório Interdisciplinar de Estudos sobre Violência e \\ Saúde, Universidade de São Paulo, São Paulo, Brasil.
}




\section{Introduction}

War conflicts claimed thousands of lives throughout the 20th century, the bloodiest century in human history 1 . However, in the early decades of the 21 st century, intentional homicide has been cited as an even more significant cause of violent death than wars 2. Each year, about half a million people worldwide - primarily young men - are victims of homicide 3 . In global terms, the number of deaths by homicide increased from 362,000 in 1990 to 464,000 in 2017 2. For comparative purposes, the number of fatalities resulting from armed conflict in 2017 was 89,0002 . Therefore, homicide ranks as a public health problem, affecting the health status of populations, with marked differences regarding gender, age, and geographical area.

Considering absolute numbers, Brazil and Nigeria - which represent $5 \%$ of the world's population - are responsible for over a quarter of global homicides 2. In 2017, the Brazilian homicide rate (30.5 per 100,000 inhabitants) was more than five times the world rate 2. In Brazil - as in all of America males are both victims and perpetrators of interpersonal violence, given that they die in greater numbers and they also commit most murders 2 . Worldwide, 8 out of 10 violent deaths involve males, and the greatest risk is in the 15-29 age bracket 2 . Brazil presents the same pattern, where almost $60 \%$ of male victims of homicide are in this age bracket 4 . Death by homicide have been increasing in the country 2,4, but with clear differences in rates of occurrence between states 4 and municipalities 5 .

Since 2001, a significant reduction in the homicide rate of São Paulo has been noted, Brazil's most populous city, and the fourth most populous in the world 6 . In less than a decade, a $74 \%$ reduction in its homicide rate has been observed 7 . The magnitude of the decline over a short period of time has been compared to that of New York (United States) in the 1990s 8 . This internationally recognized decrease in homicide mortality rates (HMR) 2,3 has been attributed to several factors such as investment in security, regulation of access to firearms 8 , reduced proportion of young people in the population 9,10 , control of unemployment levels 9,10 , and public policies in the spheres of education and culture 9 . Economic conditions (i.e., employment opportunities) and public policies to guarantee social protection can have a significant impact on income inequality and lethal violence 2 .

The risk of homicide can be divided into three time-related variables: age, period. and cohort. The effect of age expresses changes in mortality as a function of the age range. Through the period effect, we can verify if measures directed simultaneously to all, over a specific period, irrespective of age range, such as legislative measures or actions and investments in public safety, led to changes in the occurrence pattern of the outcome. On the other hand, the cohort effect assumes that the level of exposure to a particular risk factor, such as access to firearms, differs according to birth cohort, implying that the risk of death from interpersonal violence could variate depending on when a person is born 11. Thus, in age-period-cohort models, these three time-related factors are modelled: (1) a person's age at the moment of death; (2) the year when death occurred, that is, the period; and (3) the person's year of birth, corresponding to the cohort 11 .

By decomposing the time variable, these models are an advance on the trend analyses normally used in epidemiology. Thus, additional elements are provided for understanding the behavior of homicides in the main city of one of the world's most violent countries which, nevertheless, has shown substantial improvements in its rates. This study aims to estimate the effects of age, period, and birth cohort on the trend of homicide mortality, by gender, in the city of São Paulo, over the 1996-2015 period.

\section{Method}

An ecological study was performed with data on death by homicide in both sexes, with individuals aged 15 years and over, in the city of São Paulo, from 1996 to 2015. Population and mortality data were obtained, respectively, from the websites of State System of Data Analysis Foundation (SEADE; https://www.seade.gov.br/) and the Programme of Mortality Information Improvement of the São Paulo Municipal Health Department (PRO-AIM; https://www.prefeitura.sp.gov.br/cidade/ secretarias/saude/epidemiologia_e_informacao/mortalidade/index.php). Both the SEADE and the PRO-AIM are official data sources. 
The codes X-85 to Y09, Y35 and Y36 of the 10th revision of the International Classification of Diseases (ICD-10) were used. Crude annual mortality rates by gender and age group, and the standardized mortality rates were all calculated using the direct method. Therefore, Segi's world standard population of 1960 was used 12 .

Separate analyses were conducted for each sex, in which the following models were adjusted 13:

$$
\ln \left(\frac{d_{a p}}{y_{a p}}\right)=f(a)+g(p)+h(c)
$$

where $d_{a p}$ is the expected number of deaths at age $a$ and in period $p ; y_{a p}$ represents the population at risk of death at age $a$ in period $p ; f, g$ and $h$ are functions of age, period and cohort, respectively, which can be parametric or non-parametric; $a, p$ and $c$ represent the mean age, period, and cohort for the observational units, $c=p-a$; and the number of deaths follows a Poisson distribution.

It can be assumed that the number of deaths, resulting from a counting process, follows a Poisson distribution. Hence, this model allows one to assign a more satisfactory distribution for the response variable, and consider different forms for the relationship between the number of deaths and the explanatory variables (age, period, and cohort), which is often non-linear. Thus, models with different forms for the functions $f, g$ and $h$ were adjusted: a factor model with one parameter per level, and two models with smooth functions, natural splines and B-splines (polynomial functions fitted in predefined intervals, constrained to have identical values and derivatives at interval boundaries) 14 . The function which presented the best fit was selected.

Ages were grouped into five-year intervals, with the first from 15 to 19 years and the last 70 years and over, which resulted in 20 age groups. The same grouping strategy was adopted in relation to the years, resulting in four periods (1996-2000, 2001-2005, 2006-2010, and 2011-2015). In total, 16 birth cohorts were analyzed, with the first from 1921 and the last from 2000.

As mentioned, in these models, age, period and cohort are analyzed simultaneously, but to completely dissociate them as they are linearly dependent was not possible 11 . When age and period, for example, are known, it is then possible to infer the cohort. This is a limitation called the identification problem. The literature is full of attempts to overcome this problem. In this study, the approach proposed by Cartensen was used 13 .

Likelihood ratio tests were used to compare different submodels - i.e., models containing different sets of these three explanatory variables - to assess the effects of age, period and cohort. Such submodels were adjusted in a conveniently organized sequence in order to provide the tests for the mentioned effects as a comparison between them. Based on these comparisons, the best model was obtained. The adequacy of the final model fit was verified via deviance statistics.

Based on the estimates of the final model, the effects of period and cohort were graphically expressed as relative risks (RR) of death by homicide in relation to a period and a reference cohort, respectively. In this study, the reference cohort was from 1976 to 1980, while the reference period was from 2001 to 2005 . The age effect was presented graphically as homicide mortality rates (per 100,000 inhabitants) according to age, adjusted in the cohort, and reference period.

Data analysis and graphs were done in R ("Epi" package) (http://www.r-project.org). This study was not submitted to a Research Ethics Committee, as it uses only publicly accessible data.

\section{Results}

From 1996 to 2015, 61,131 male deaths and 4,808 female deaths by homicide were registered, in the age groups of 15 or over, in the city of São Paulo. More than half of these deaths occurred in the 15-29 age bracket. When the years 1996 and 2015 were compared, a fall in the crude HMR in all age groups was found, as well as in the standardized HMR, for both males and females (Table 1). The highest standardized HMR in males $(133.68 / 100,000)$ and females $(9.5 / 100,000)$ were observed in 2001 and 2000 , respectively. 
Homicide mortality rates (per 100,000 inhabitants), according to age and sex. City of São Paulo, Brazil, 1996-2015.

\begin{tabular}{|c|c|c|c|c|c|c|c|c|}
\hline \multirow[t]{3}{*}{ Age groups (years) } & \multicolumn{4}{|c|}{ Male } & \multicolumn{4}{|c|}{ Female } \\
\hline & \multirow[t]{2}{*}{$\mathbf{n}$} & \multirow[t]{2}{*}{$\%$} & \multicolumn{2}{|c|}{ Rate } & \multirow[t]{2}{*}{$\mathbf{n}$} & \multirow[t]{2}{*}{$\%$} & \multicolumn{2}{|c|}{ Rate } \\
\hline & & & 1996 & 2015 & & & 1996 & 2015 \\
\hline $15-19$ & 10,298 & 16.8 & 152.5 & 67.2 & 801 & 16.7 & 13.7 & 1.6 \\
\hline $20-24$ & 14,124 & 23.1 & 209.5 & 55.7 & 889 & 18.5 & 14.8 & 3.2 \\
\hline $25-29$ & 11,662 & 19.1 & 205.9 & 39.8 & 788 & 16.4 & 8.0 & 3.9 \\
\hline $30-34$ & 8,613 & 14.1 & 154.8 & 33.7 & 609 & 12.7 & 9.1 & 2.9 \\
\hline $35-39$ & 5,946 & 9.7 & 112.7 & 27.7 & 486 & 10.1 & 7.0 & 3.1 \\
\hline $40-44$ & 4,089 & 6.7 & 89.5 & 27.2 & 415 & 8.6 & 5.9 & 3.1 \\
\hline $45-49$ & 2,674 & 4.4 & 65.4 & 20.9 & 266 & 5.5 & 4.5 & 1.4 \\
\hline $50-54$ & 1,535 & 2.5 & 46.3 & 16.6 & 168 & 3.5 & 5.9 & 1.6 \\
\hline $55-59$ & 914 & 1.5 & 39.1 & 13.1 & 134 & 2.8 & 6.5 & 0.9 \\
\hline $60-64$ & 599 & 1.0 & 25.1 & 7.6 & 79 & 1.6 & 4.3 & 2.8 \\
\hline $65-69$ & 313 & 0.5 & 15.9 & 12.4 & 53 & 1.1 & 1.6 & 0.9 \\
\hline$>70$ & 364 & 0.6 & 12.4 & 9.3 & 120 & 2.5 & 1.8 & 1.2 \\
\hline Standardized rate & & & 113.3 & 32.9 & & & 8.0 & 2.4 \\
\hline
\end{tabular}

Although male HMR were consistently higher than female HMR (Table 1), the behavior of the series according to age, period, and cohort followed a similar pattern for both sexes (Figures 1 and 2). Regardless of the period, the highest HMR occurred in the 20-24 age bracket and, thereafter, decreased as age increased (Figures 1a and 2a). Higher HMR were found among males born in the 1971, 1976, and 1981 cohorts (Figure 1b), and in females born in the 1976 and 1981 cohorts (Figure 2b). In almost all age groups, a very considerable drop in HMR between 2002 and 2006 for both sexes was detected, which became less evident in subsequent years (Figures 1c and 2c). A downward trend in HMR in all age groups was observed, regardless of the birth cohort (Figures $1 \mathrm{~d}$ and $2 \mathrm{~d}$ ).

The complete model - namely that model with age-period-cohort effects - showed better adjustment to the data when compared to others, in both sexes, considering the lowest deviance (Table 2).

Figure 3 shows that, irrespective of sex, the highest HMR occurred between 20 and 24 years, and progressively decreased as age increased from this age group onwards. The highest risk of death was found between 1996 and 2000, with RRs of 1.37 (95\%CI: 1.35; 1.39) and 1.36 (95\%CI: 1.31; 1.42) for males and females, respectively. A reduction in the risk of death by homicide over the periods was detected, although with a lower declining intensity in the final five years (2011-2015), for both males $(\mathrm{RR}=0.48$; 95\%CI: 0.46 ; 0.49) and females $(\mathrm{RR}=0.52$; $95 \% \mathrm{CI}$ : $0.47 ; 0.57)$.

When compared with the reference cohort (1976-1980), the risk of death from homicide in males born after the 1970s declined but the protective effect was reduced in the most recent cohort. The last two birth cohorts analyzed, 1991 to 1995 and 1996 to 2000, presented an RR equal to 0.67 (95\%CI: $0.64 ; 0.71)$ and 0.87 (95\%CI: $0.81 ; 0.94)$, respectively. Males born in the 1950 s and 1960 s presented a higher risk of death compared to others. The highest RR value was found in the birth cohort from 1956 to 1960 ( $\mathrm{RR}=1.23$; 95\% CI: 1.17; 1.30). For females, a progressive reduction in RR from the 1980s onwards was found, and the RR of the final birth cohort (1996-2000) was 0.62 (95\%CI: 0.48; 0.80 ). The highest risk of death was found in the 1961 to 1965 birth cohort ( $R R=1.19$; 95\%CI: 1.04; 1.36). 


\section{Figure 1}

Male homicide mortality rates (per 100,000 inhabitants), according to age and period, period and age, age and birth cohort, and birth cohort and age. City of São Paulo, Brazil, 1996-2015.

1a) Age and period

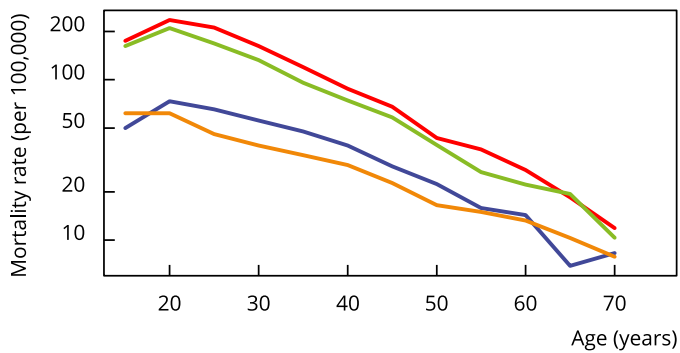

\section{Period}

$-1996$

2001

2006

2011

1b) Period and age

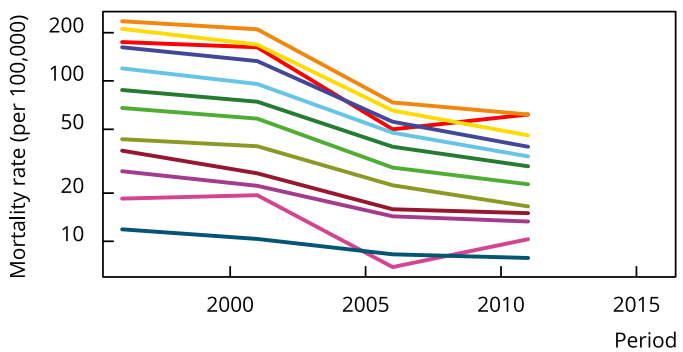

Age (years)

$-15-45$

$-20-50$

$-25-55$

$-30-60$

$-35-65$

$-40-70$

1c) Age and birth cohort

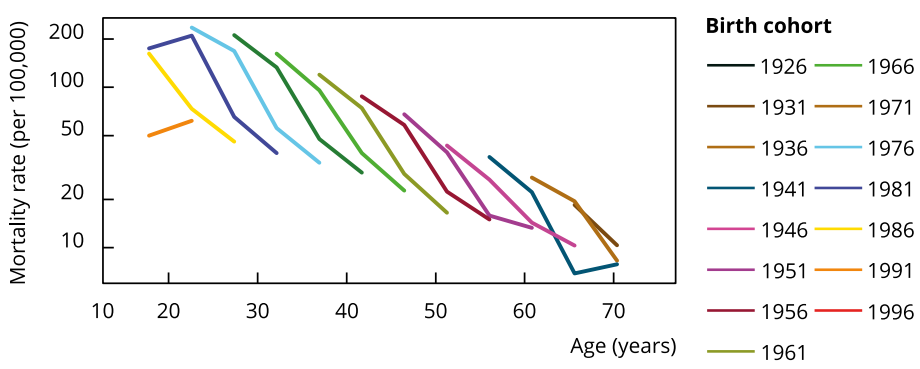

1d) Birth cohort and age

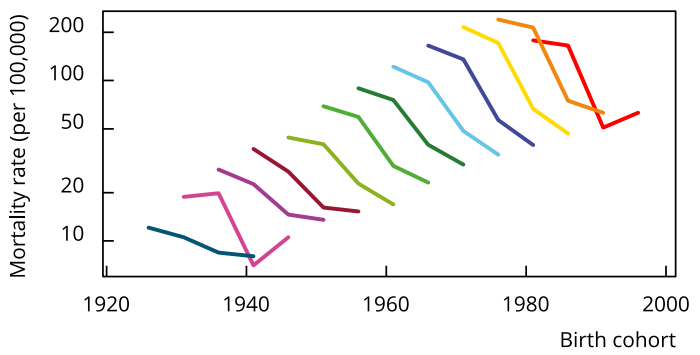

Age (years)

$-15-45$

$-20=50$

$-25-55$

$-30-60$

$-35-65$

$-40-70$ 


\section{Figure 2}

Female homicide mortality rates (per 100,000 inhabitants), according to age and period, period and age, age and birth cohort, and birth cohort and age. City of São Paulo, Brazil, 1996-2015.

2a) Age and period
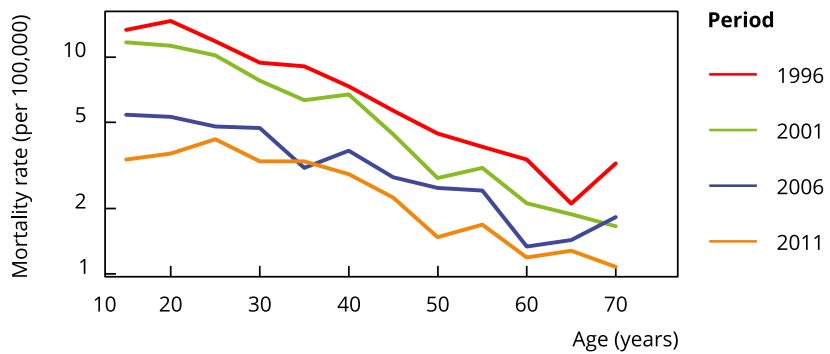

2b) Period and age

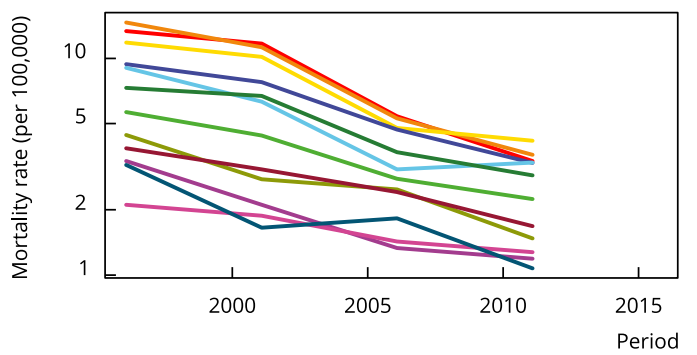

Age (years)

$-15-45$

$-20-50$

$-25-55$

$-30-60$

$-35-65$

$-40-70$

2c) Age and birth cohort

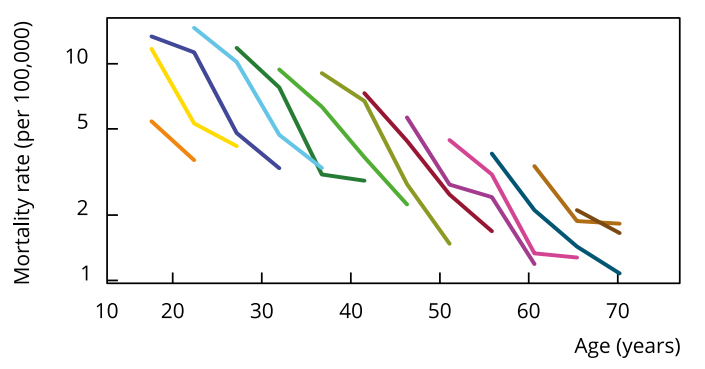

\section{Birth cohort}

- $1926-1966$

- $1931-1971$

$-1936-1976$

$-1941-1981$

$-1946-1986$

$-1951-1991$

$-1956-1996$

2d) Birth cohort and age

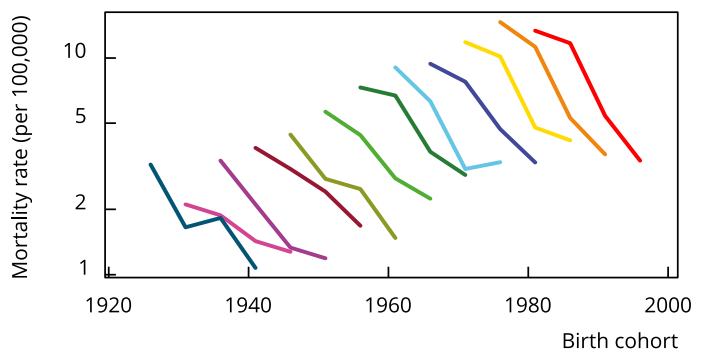

Age (years)

$-15-45$

$-20-50$

$-25-55$

$-30-60$

$-35-65$

$-40-70$ 
Table 2

Models' estimates of the age-period-cohort effect for mortality due to homicide, by sex. City of São Paulo, Brazil, 1996-2015.

\begin{tabular}{|c|c|c|c|c|c|c|c|c|c|c|}
\hline \multirow[t]{2}{*}{ Model * } & \multicolumn{5}{|c|}{ Male } & \multicolumn{5}{|c|}{ Female } \\
\hline & Deviance & df & Deviance ** & df $* *$ & p-value *** & Deviance & df & Deviance ** & df ** & p-value $* * *$ \\
\hline Age & 16,671 & 36 & & & & 940 & 36 & & & \\
\hline Age-drift & 2,118 & 35 & 14,553 & 1 & $<0.0001$ & 86 & 35 & 853 & 1 & $<0.0001$ \\
\hline Age-cohort & 1,667 & 22 & 451 & 13 & $<0.0001$ & 50 & 22 & 36 & 13 & 0.0006 \\
\hline Age-period-cohort & 200 & 20 & 1,467 & 2 & $<0.0001$ & 18 & 20 & 32 & 2 & $<0.0001$ \\
\hline Age-period & 527 & 33 & 327 & 13 & $<0.0001$ & 52 & 33 & 33 & 13 & 0.0015 \\
\hline Age-drift & 2,118 & 35 & 1,591 & 2 & $<0.0001$ & 86 & 35 & 35 & 2 & $<0.0001$ \\
\hline
\end{tabular}

df: degrees of freedom.

* Models are ordered so that adjacent rows provide tests between models, culminating in the age-period-cohort model;

** Changes in residual df and deviance between models on the current line and the previous line in the table;

$* \star *$ p-value of the likelihood ratio test that compares the models of the current and the previous line in the table.

\section{Discussion}

This is the first report investigating homicide rates using age-period-cohort models in the city of São Paulo. We observed that individuals aged 20-24 years had the highest risk of dying. Furthermore, we found a dramatic reduction in the homicide risk regardless of sex and age groups, as well as a decreased risk in recent cohorts when compared with older groups. However, these reductions in mortality trends are diminishing its intensity over time, revealing limitations in the effectiveness of public policies to maintain these achievements.

The major world cities have been more successful in dropping lethal violence than their respective countries due to its better infrastructure, public management, security, and justice systems than non-urban areas 2 . In the city of São Paulo, we found a noteworthy reduction in deaths due to interpersonal violence for different cohorts and periods, while Brazil presented a substantial rise in the homicide rates, with an estimated prevalence of homicide 2.4-fold higher than this metropolis in 2017 4,15. Nevertheless, the city of São Paulo has faced an unusual phenomenon regarding its sharp overall reduction on homicide rates, while most of the Brazilian state capital cities had upward trends 15. For instance, this city had an estimated prevalence of 13.2 deaths per 100,000 inhabitants in 2017, whereas the cities of Fortaleza (Ceará State), Rio Branco (Acre State), and Belém (Pará State) showed the highest homicide rates of $87.9,85.3$, and 74.3 deaths per 100,000 inhabitants, respectively 4,15. Our data are consistent with previous studies 7,8 , and, in part, resemble the trajectory experienced by cities in high-income countries. However, our homicide rates are still higher than other major cities, such as Nairobi, Mombasa, and Kisumu in Kenya 2. In our analysis, we observed a stable pattern after 2008, which emphasizes the impact of macro-conditions on these reductions more than directed interventions for high-risk areas or population subgroups, and also the overall drop affected all age groups and cohorts.

In New York City, violent crimes declined due to changes in policing policy and the decreased cocaine use in the 1990s 16,17,18. The magnitude of these changes affected more blacks and Hispanics than whites ${ }^{19}$. Hence, this homicide drop was heterogeneous and focused on disadvantaged minority communities instead of considering the whole population 20 . Conversely, our analysis showed a decreased risk of dying with similar patterns, irrespective of sex, age group, period, or birth cohort. In parallel, the risk rate reduced dramatically, underscoring an age-period-cohort effect among males and females. In other words, these findings evidenced that exposure experiences on lethal violence in the city of São Paulo have shifted overtime positively for the whole population. 
Figure 3

Estimates of the age-period-cohort model adjusted for mortality due to homicide in males and females. City of São Paulo, Brazil, 1996-2015.

3a) Males

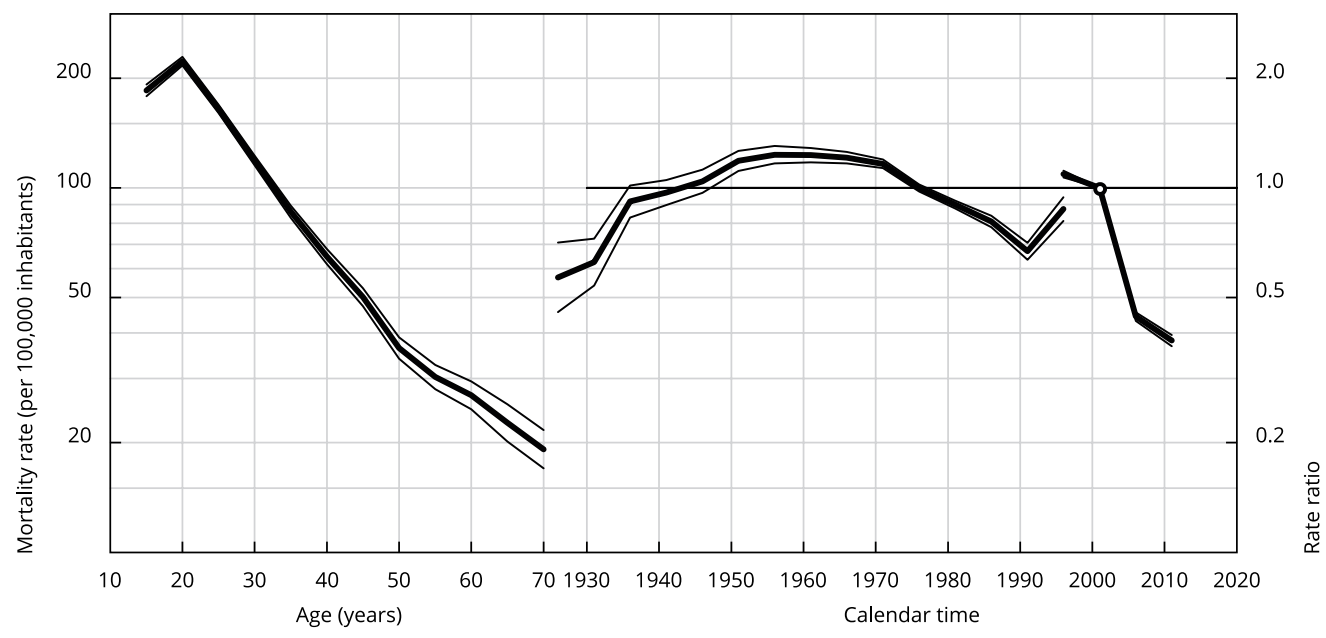

3b) Females

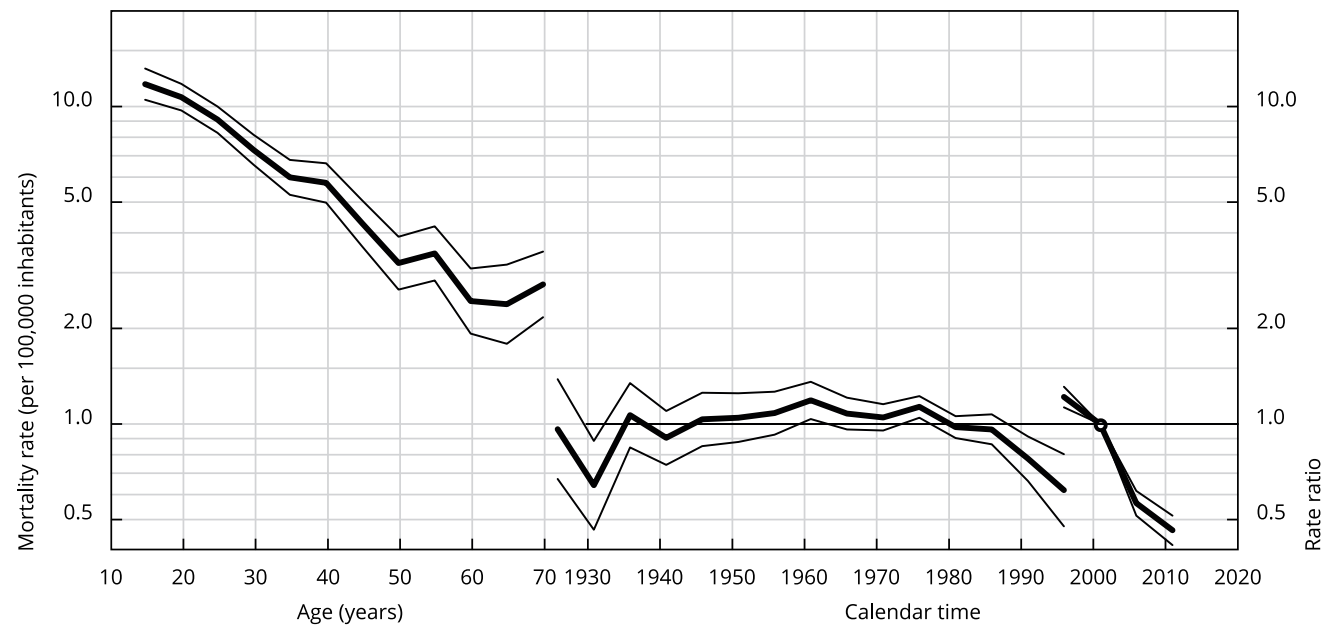

In São Paulo, the high homicide rates in the late 1990s dropped after investments and reforms that triggered innovations in the management culture of police organizations. Accordingly, the policing methods have used more data-driven decision-making 8 (e.g., Infocrim system), community policing, performance evaluations 21 , and improvements in human resources training seeking to reduce its high rates of lethal homicides 7. Also, the public safety budget increased 169.5\% in São Paulo State (1997-2008), as well as the incarceration rate rose by 89.7\% from 1996 to 2008 9. In Brazil, the risk of dying by firearms is 2.6 -fold higher than any other country, and about $70 \%$ of deaths due to interpersonal violence occurred by firearms 21 . Consequently, the enforcement of strict gun-control legislation at state and national levels 22 affected firearms deaths 8 , which decreased by $74.1 \%$ in the early 2000s until 2008 7. Therefore, the disarmament policy reduced the availability of guns in the city of 
São Paulo 22, which associated with alcohol restrictions policy (Lei Seca) 23, supports the overall drop in lethal violence found in our investigation.

In this study, the homicide rates peaked for young adults of both sexes, which is consistent with other studies 2,24, but the risk of dying by homicide reduced overtime irrespective of birth cohorts. In the city of São Paulo, we hypothesized that the reduction of $18.8 \%$ in the proportion of the youth population between 2001 and 2008 9, and the baby boom of the 1960s 24 explains our findings. Homicide rates rose in the late 1990s and, subsequently, reached a lower level after its effects in early to mid-2000s. In Latin America and worldwide, a significant correlation between the proportion of young adults without an occupation and lethal violence 2,25 was found, particularly among people with lower levels of formal education 24. Further, there is a mutual interaction between education and violence 26 . In Brazilian municipalities, a rise in the dropout rate by $1 \%$ augments the homicide rate by $0.18 \%$ on average 27 . As a result, it limits economic opportunities for youth leading them to a vicious cycle of violence 23 . Hence, to broaden the education access is crucial to reduce violence and crimes due to its protective conditions 2 .

Although São Paulo city is an heterogenous urban location with socioeconomic issues, the unemployment rate reduced by $18.6 \%$ from 2001 to 200828 . This data is consistent with our findings once its effects on interpersonal violence in young people. Likewise, the culture and education expenditure rose $47.1 \%$ in this location (1996-2008), presenting a positive correlation with homicide rates. Moreover, the conditional cash transfer program, or Bolsa Familia, covered about 59 more students per school between 2006 and 2009, representing 21\% fewer crimes in school neighbourhoods 29. Hence, these interventions seem to contribute to our analysis comprehension because of its positive effects on drug-related, robberies, and violent crimes in the city of São Paulo 30.

In summary, we hypothesized that general homicide drop found in our investigation occurred due to several macro determinants. For instance, the disarmament policy and alcohol restrictions; reduced income inequality; raised school attendance among the youth population; demographic changes; policing methods innovations; and a reduction in the crack epidemic cycle 31 . To continue declining lethal violence in São Paulo city is critical to address challenges referred to lethal violence 2. For that, public policies should focus on strengthening the criminal justice response on homicide crimes and social welfare systems; alcohol and firearms restrictions; education and employment opportunities among the young population; the use community-level data to monitor youth violence 28; and effective intersectoral interventions for violence prevention empowerment of communities 32 , especially in the most vulnerable social strata.

This study had limitations that are relevant to its interpretation. In ecological studies, associations found at population-level may not occur at the individual level. Also, the city of São Paulo's police force is related to a rate of civilians' death higher than the national rate. Thus, legal interventions and operations of war represented $13.8 \%$ of all homicides in this research in 2015. Despite data quality improvement over time, we classified deaths due to interpersonal violence based on the Bogotá Protocol to diminish the effects of killings by state agents on our observations and to allow comparisons across countries 33. Further, this study did not include information on macro-level conditions or race-specific homicide rates, which restricted our analysis. We used public datasets susceptible to measurement errors or misclassification (information bias); however, homicide is the most reliable data on violence in Brazil 34. Also, the city of São Paulo comprises almost 6\% of all Brazilian population. Hence, its successful experience on lethal violence drop contributes to homicide knowledge in Brazil and Latin America, which is a region with epidemic statistics.

\section{Conclusions}

In our age-period-cohort analysis, we can hypothesize that macro determinants justify this overall dramatic drop in homicide risk in the city of São Paulo. Conversely, the progress in cut-off on homicide rates depends on revisions in public policies to consider innovations and policymaking focused on vulnerable areas, thus tackling inequality and socioeconomic issues. In that sense, it should include social protection, particularly for young adults, policing qualification, and effective justice systems with an improved criminal enforcement process to ensure the control of prisons. 


\section{Contributors}

F. R. Andrade and F. S. Menezes collected data, performed statistical analysis, and prepared the first draft of the manuscript. M. M. Oliveira, G. M. S. Conceição, M. F. T. Peres, and M. R. D. O. Latorre conceived, designed, and planned the study, and interpreted the results. All authors approved the final version of the manuscript.

\section{Additional informations}

ORCID: Flávia Reis de Andrade (0000-0001-94610325); Fabrício dos Santos Menezes (0000-00019230-1879); Max Moura de Oliveira (0000-00020804-5145); Gleice Margarete de Souza Conceição (0000-0002-5930-9024); Maria Fernanda Tourinho Peres (0000-0002-7049-905X); Maria do Rosário Dias de Oliveira Latorre (0000-0002-5189-3457).

\section{References}

1. United Nations Development Programme. Human Development Report 2005. International cooperation at a crossroads: aid, trade and security in an unequal world. http://hdr. undp.org/sites/default/files/reports/266/ hdr05_complete.pdf (accessed on $01 /$ Apr/2020).

2. United Nations Office on Drugs and Crime. Global study on homicide. 2019 edition. https://www.unodc.org/unodc/en/data-andanalysis/global-study-on-homicide.html (accessed on 11/Jul/2019).

3. World Health Organization. Global status report on violence prevention 2014. https:// www.who.int/violence_injury_prevention/ violence/status_report/2014/en/ (accessed on 11/Jul/2019).

4. Instituto de Pesquisa Econômica Aplicada; Fórum Brasileiro de Segurança Pública. Atlas da violência 2019. http://www.ipea.gov.br/ portal/index.php?option $=$ com_content\&vie $\mathrm{W}=$ article \&id $=34784 \&$ Itemid $=432$ (accessed on $01 /$ Nov/2019).

5. Peres MFT, Nivette A. Social disorganization and homicide mortality rate trajectories in Brazil between 1991 and 2010. Soc Sci Med 2017; 190:92-100.

6. United Nations. The world's cities in 2018. https://www.un-ilibrary.org/human-settle ments-and-urban-issues/the-world-s-citiesin-2018_c93f4dc6-en (accessed on 23/ $\mathrm{Jul} / 2019)$.

7. Peres MFT, Vicentin D, Nery MB, Lima RS, Souza ER, Cerda M, et al. Queda dos homicídios em São Paulo, Brasil: uma análise descritiva. Rev Panam Salud Pública 2011; 29:17-26.

8. Goertzel T, Kahn T. The great São Paulo homicide drop. Homicide Stud 2009; 13:398-410.

9. Peres MFT, Almeida JF, Vicentin D, Cerda M, Cardia N, Adorno S. Fall in homicides in the city of São Paulo: an exploratory analysis of possible determinants. Rev Bras Epidemiol 2011; 14:709-21.

10. Peres MFT, Almeida JF, Vicentin D, Ruotti C, Nery MB, Cerda M, et al. Evolução dos homicídios e indicadores de segurança pública no Município de São Paulo entre 1996 a 2008: um estudo ecológico de séries temporais. Ciênc Saúde Colet 2012; 17:3249-57.

11. Holford TR. Understanding the effects of age, period, and cohort on incidence and mortality rates. Annu Rev Public Health 1991; 12:425-57.

12. Ahmad OB, Boschi-Pinto C, Lopez AD, Murray $\mathrm{CJL}$, Lozano $\mathrm{R}$, Inoue $\mathrm{M}$. Age standardization of rates: a new WHO standard. Geneva: World Health Organization; 2001. (GPE Discussion Paper Series, 31).

13. Carstensen B. Age-period-cohort models for the Lexis diagram. Stat Med 2007; 26:3018-45.

14. Heuer C. Modeling of time trends and interactions in vital rates using restricted regression splines. Biometrics 1997; 53:161-77. 
15. Instituto de Pesquisa Econômica Aplicada; Fórum Brasileiro de Segurança Pública. Atlas da violência: retratos dos municípios brasileiros. http://www.ipea.gov.br/atlasviolencia/down load/21/atlas-da-violencia-dos-municipiosbrasileiros-2019 (accessed on 01/Nov/2019).

16. Cerdá M, Tracy M, Messner SF, Vlahov D, Tardiff K, Galea S. Misdemeanor policing, physical disorder, and gun-related homicide: a spatial analytic test of 'broken-windows' theory. Epidemiology 2009; 20:533-41.

17. Messner SF, Galea S, Tardiff KJ, Tracy M, Bucciarelli A, Piper TM, et al. Policing, drugs, and the homicide decline in New York city in the 1990s. Criminology 2007; 45:385-414.

18. Cerdá M, Messner S, Tracy M, Vlahov D, Goldmann E, Tardiff KJ, et al. Investigating the effect of social changes on age-specific gun-related homicide rates in New York City during the 1990s. Am J Public Health 2010; 100:1107-15.

19. Chauhan P, Cerda M, Messner SF, Tracy M, Tardiff K, Galea S. Race/ethnic-specific homicide rates in New York City: evaluating the impact of broken windows policing and crack cocaine markets. Homicide Stud 2011; 15:268-90.

20. Rosenfeld R, Fornango R, Rengifo AF. The impact of order-maintenance policing on New York City homicide and robbery rates: 1988-2001. Criminology 2007; 45:355-84.

21. World Bank. Making Brazilians safer: analyzing the dynamics of violent crime. http://documents.worldbank.org/curated/ pt/252761468015010162/pdf/707640ESW0 REVIOics0ofOViolent0Crime.pdf (accessed on 01/Nov/2019).

22. dos Santos MJ, Kassouf AL. A cointegration analysis of crime, economic activity, and police performance in São Paulo city. J Appl Stat 2013; 40:2087-109.

23. Biderman C, De Mello JMP, Schneider A. Dry laws and homicides: evidence from the São Paulo Metropolitan Area. Econ J (London) 2010; 120:157-82.

24. Reichenheim ME, Souza ER, Moraes CL, Mello-Jorge MHP, Silva CMFP, Minayo MCS. Violence and injuries in Brazil: the effect, progress made, and challenges ahead. Lancet 2011; 377:1962-975.

25. de Hoyos R, Popova A, Rogers H. Out of school and out of work: a diagnostic of ninis in Latin America. Washington DC: The World Bank; 2016.
26. Barrera F, Ibáñez AM. Does violence reduce investment in education? A theoretical and empirical approach. Documentos CEDE, 002382. https://ideas.repec.org/p/col/000089/002382. html (accessed on 31/Aug/2019).

27. Chioda L. Stop the violence in Latin America: a look at prevention from cradle to adulthood. Washington DC: The World Bank; 2017. (Latin American Development Forum).

28. Masho SW, Schoeny ME, Webster D, Sigel E. Outcomes, data, and indicators of violence at the community level. J Prim Prev 2016; 37:121-39.

29. Chioda L, Mello JMP, Soares RR. Spillovers from conditional cash transfer programs: Bolsa Família and crime in urban Brazil. http://www.econ.puc-rio.br/uploads/adm/ trabalhos/files/td599.pdf (accessed on 11/ Sep/2019).

30. Chioda L, De Mello JMP, Soares RR. Spillovers from conditional cash transfer programs: Bolsa Família and crime in urban Brazil. Econ Educ Rev 2016; 54:306-20.

31. Justus M, de Castro Cerqueira DR, Kahn T, Moreira GC. The "São Paulo Mystery": the role of the criminal organization PCC in reducing the homicide in 2000s. EconomiA 2018; 19:201-18.

32. Matzopoulos R, Bowman B, Mathews S, Myers J. Applying upstream interventions for interpersonal violence prevention: an uphill struggle in low- to middle-income contexts. Health Policy 2010; 97:62-70.

33. Cámara de Comercio de Bogotá; Open Society Foundations; Fiscalía General de la Nación; Ministerio de Justicia y del Derecho; Laboratório de Análise da Violência, Universidade do Estado do Rio de Janeiro. Protocolo de Bogotá sobre calidad de datos de homicidio en América Latina y el Caribe. https:// bibliotecadigital.ccb.org.co/bitstream/hand le/11520/14026/12\%20Calidad\%20de\%20 datos-entregable-ESPA\%c3\%91OL_PRINT_ por_paginas.pdf? sequence $=1 \&$ isAllowed $=y$ (accessed on 11/Sep/2019).

34. Murray J, Cerqueira DRC, Kahn T. Crime and violence in Brazil: systematic review of time trends, prevalence rates and risk factors. Aggress Violent Behav 2013; 18:471-83. 


\section{Resumo}

Embora São Paulo seja a cidade mais populosa do Brasil, que é um dos países mais violentos do mundo, o município vem apresentando uma redução significativa na taxa de mortalidade por homicídio (TMH). O estudo buscou estimar os efeitos de idade, período e coorte de nascimentos na tendência da mortalidade por homicídio de acordo com sexo na cidade de São Paulo, entre 1996 e 2015. Foi realizado um estudo ecológico com dados sobre óbitos por homicídio em ambos os sexos, em todas as faixas etárias, no local e periodo mencionados acima. Foram ajustados modelos de Poisson para cada sexo, para estimar os efeitos de idade-período-coorte. Foram registrados 61.833 óbitos por homicídio em homens e 5.109 em mulheres. Independentemente do período, a TMH mais alta ocorreu na faixa etária de 20-24 anos. As TMH mais altas foram observadas em indivíduos que nasceram nas décadas de 1970 e 1980. O melhor ajuste para os dados foi como o modelo completo, com os efeitos de idade-periodo-coorte. O risco e óbitos por homicídio diminuiu ao longo dos anos, com a menor intensidade nos últimos cinco anos (2011-2015), tanto em homens $(R R=0,48 ;$ IC95\%: 0,46; 0,49) quanto em mulheres $(R R=0,52$; IC95\%: 0,47; 0,57 ). Foi observada uma redução no risco de homicídio, independente de sexo ou faixa etária, como também, nas coortes mais recentes. Entretanto, a intensidade dessas reduções tem diminuído ao longo do tempo, sugerindo que as politicas públicas adotadas têm potencial limitado para manter os avanços alcançados.

Homicídio; Efeito Idade; Efeito Período; Efeito de Coortes

\section{Resumen}

A pesar de que São Paulo es la cuidad más poblada en Brasil, uno de los países más violentos del mundo, ha estado mostrando una significativa reducción en su tasa de mortalidad por homicidios (TMH). Este estudio se propone estimar los efectos de la edad, periodo, y cohorte de nacimiento sobre la tendencia de la mortalidad por homicidio, según sexo, en la ciudad de Sao Paulo, de 1996 a 2015. Se realizó un estudio ecológico con datos sobre las muertes por homicidio en ambos sexos, en todos los grupos de edad, en el lugar y período mencionado previamente. Con el fin de estimar los efectos de la edad-periodo-cohorte, se ajustaron modelos Poisson para ambos sexos. Se registraron un total de 61.833 muertes por homicidio entre hombres $y$ 5.109 entre mujeres. Independientemente del periodo, la TMH más alta se produjo en la franja de edad 20-24. Unas TMH más altas se observaron en quienes habian nacido en los 1970 y los 1980. El modelo completo, con los efectos edad-períodocohorte, fue la mejor manera de ajustar los datos. El riesgo de muerte por homicidio se redujo a lo largo de los periodos, con una intensidad más baja en los últimos cinco años (2011-2015), para tanto hombres ( $R R=0,48$; IC95\%: 0,46; 0,49), como mujeres $(R R=0,52$; IC95\%: 0,47; 0,57). Se observó una reducción en el riesgo de homicidio, independientemente del sexo o franja de edad, así como en las cohortes recientes. No obstante, la intensidad de tales reducciones ha estado decreciendo a lo largo del tiempo, lo que sugiere que las politicas públicas adoptadas tienen un potencial limitado para mantener estos logros.

Homicidio; Efecto Edad; Efecto Periodo;

Efecto de Cohortes
Submitted on 27/Aug/2020

Final version resubmitted on $09 / \mathrm{Feb} / 2021$

Approved on 04/Mar/2021 